\title{
Impaired T-cell and antibody immunity after COVID-19 infection in chronically immunosuppressed transplant recipients
}

Chethan Ashokkumar, $\mathrm{PhD}^{1,2}$, Vinayak Rohan, $\mathrm{MD}^{3}$, Alexander $\mathrm{H}$ Kroemer, $\mathrm{MD}, \mathrm{PhD}^{4}$, Sohail Rao, MD, $\mathrm{PhD}^{5}$, George Mazariegos, $\mathrm{MD}^{2}$, Brandon W Higgs, $\mathrm{PhD}^{2}$, Satish Nadig, $\mathrm{MD}, \mathrm{PhD}^{3}$, Jose Almeda, $\mathrm{MD}^{5}$, Harmeet Dhani, $\mathrm{MD}^{4}$, Khalid Khan, $\mathrm{MD}^{4}$, Nada Yazigi MD , Udeme Ekong $\mathrm{MD}^{4}$, Stuart Kaufman $\mathrm{MD}^{4}$, Monica M Betancourt-Garcia, $\mathrm{MD}^{5}$, Kavitha Mukund, $\mathrm{PhD}^{6}$, Pradeep Sethi, MD${ }^{1}$, Shikhar Mehrotra, $\mathrm{PhD}^{3}$, Kyle Soltys, $\mathrm{MD}^{2}$, Manasi S Singh, $\mathrm{MD}^{3}$, Geoffrey Bond, $\mathrm{MD}^{2}$, Ajai Khanna, $\mathrm{MD}^{2}$, Mylarappa Ningappa, $\mathrm{PhD}^{2}$, Brianna Spishock, BS ${ }^{1}$, Elizabeth Sindhi ${ }^{1}$, Neha Atale, $\mathrm{PhD}^{1}$, Maggie Saunders, $\mathrm{BS}^{1}$, Prabhakar Baliga, $\mathrm{MD}^{3}$, Thomas Fishbein, $\mathrm{MD}^{4}$, Shankar Subramaniam, $\mathrm{PhD}^{6}$, and Rakesh Sindhi, MD. ${ }^{1,2}$

Plexision Inc., Pittsburgh, PA 1 , Hillman Center for Pediatric Transplantation, University of

Pittsburgh, $\mathrm{PA}^{2}$, Medical University of South Carolina, Charleston, $\mathrm{SC}^{3}$, Medstar Georgetown

Transplant Institute, Washington, DC4 ${ }^{4}$ DHR Health and DHR Health Institute for Research and Development, Edinburg, Tx, University of Houston, Houston, TX ${ }^{5}$, and the University of California, San Diego, $\mathrm{CA}^{6}$-all in United States of America.

Corresponding author:

Rakesh Sindhi, MD, FACS

UPMC Children's Hospital of Pittsburgh

4401 Penn Ave., FP-6/Transplant, Rm 6140

Pittsburgh, PA 15224

Email: rakesh.sindhi@chp.edu

Phone: 412-692-7849 
Abbreviations: cell-mediated immunity (CMI), SARS-CoV-2 (SARS2), healthy-non transplant (HNT), healthy transplant (H-Tr), COVID-19 transplant (Tr), COVID-19 non-transplant (NT), true positive (TP), false negative (FN), peripheral blood leukocytes (PBL). monocytic- and polymorphonuclear-MDSC (M-MDSC and P-MDSC). 
Abstract: Assessment of T-cell immunity to the COVID-19 coronavirus requires reliable assays and is of great interest, given the uncertain longevity of the antibody response. Some recent reports have used immunodominant spike (S) antigenic peptides and anti-CD28 co-stimulation in varying combinations to assess T-cell immunity to SARS-CoV-2. These assays may cause T-cell hyperstimulation and could overestimate antiviral immunity in chronically immunosuppressed transplant recipients, who are predisposed to infections and vaccination failures. Here, we evaluate CD154-expressing T-cells induced by unselected S antigenic peptides in 204 subjects103 COVID-19 patients and 101 healthy unexposed subjects. Subjects included 72 transplanted and 130 non-transplanted subjects. S-reactive CD154+T-cells co-express and can thus substitute for IFN $\gamma(n=3)$. Assay reproducibility in a variety of conditions was acceptable with coefficient of variation of $2-10.6 \%$. S-reactive CD154+T-cell frequencies were a) higher in 42 healthy unexposed transplant recipients who were sampled pre-pandemic, compared with 59 healthy non-transplanted subjects $(p=0.02)$, b) lower in Tr COVID-19 patients compared with healthy transplant patients $(p<0.0001), c)$ lower in $\operatorname{Tr}$ patients with severe COVID-19 $(p<0.0001)$, or COVID-19 requiring hospitalization $(\mathrm{p}<0.05)$, compared with healthy $\mathrm{Tr}$ recipients. S-reactive Tcells were not significantly different between the various COVID-19 disease categories in NT recipients. Among transplant recipients with COVID-19, cytomegalovirus co-infection occurred in 34\%; further, CMV-specific T-cells $(p<0.001)$ and incidence of anti-receptor-binding-domain IgG $(p=0.011)$ were lower compared with non-transplanted COVID-19 patients. Healthy unexposed transplant recipients exhibit pre-existing T-cell immunity to SARS-CoV-2. COVID-19 infection leads to impaired T-cell and antibody responses to SARS-CoV-2 and increased risk of CMV coinfection in transplant recipients. 
Introduction: In chronically immunosuppressed transplant recipients ( $\mathrm{Tr}$ ), the status of immunity to COVID-19 infection is of great interest. This population is prone to life-threatening consequences of viral infection and failure of vaccination during periods marked by use of highdose immunosuppression ${ }^{1}$. Lifelong use of anti-rejection immunosuppressants contributes to this impairment and may also limit post-infectious and post-vaccination immunity to SARS-CoV-2 ${ }^{2,3}$. Although antibodies can be demonstrated after natural COVID-19 infection and vaccination in the general population, this information is not available for Tr recipients ${ }^{4-11}$. Pre-existing T-cells that recognize SARS-CoV-2 are another component of immunity to this virus ${ }^{12-15}$. This type of immunity arises from prior exposure to human coronaviruses (hCoV), which account for $15 \%$ of seasonal flu and have structural similarities to SARS-CoV-2 ${ }^{16-17}$. Pre-existing cellular immunity may also compensate for impaired antibody responses to COVID-19 infection and vaccination, and aid in combating variant strains that are starting to emerge. T-cell immunity may also reassure those individuals wishing to re-engage with the general public, but who are unable to tolerate vaccination or fail to achieve a durable antibody response. Pre-existing cellular immunity to SARS-CoV-2 has been demonstrated in non-transplanted subjects, but not in Tr recipients ${ }^{12-15}$.

Recently proposed assays which measure T-cell immunity to SARS-CoV-2 may need to be modified to characterize T-cell immunity in Tr recipients. Some assays stimulate T-cells with those peptides representing the spike protein $S$, which have high affinity to well represented HLA specificities in a given population ${ }^{13,14}$. Such peptide mixtures can potentially overstimulate T-cells from individuals with these HLA specificities, but not T-cells from underrepresented individuals. Other assays also use the co-stimulators, anti-CD28 alone, or with anti-CD49d ${ }^{12,14}$. These adjunctive stimuli can also lead to an overestimate of T-cell immunity. Clinical decisions founded on such overestimates can be falsely reassuring in chronically immunosuppressed patients, and lead to errors in clinical judgement with adverse consequences. Some assays also use cytotoxic intracellular staining procedures, or only count those cells which co-express multiple markers as 
antigen-reactive. Such multi-marker assays require large numbers of cells from individuals with COVID-19 infection, who can be severely lymphopenic, and sophisticated laboratories. Another challenge is extrapolating findings from these studies, all of which have been performed in nontransplant (NT) subjects who were recently diagnosed or were convalescing, to Tr recipients. Higher frequencies of S-reactive T-cells were observed in convalescent and non-critically ill COVID-19 NT patients compared with healthy unexposed individuals. S-reactive frequencies were undetectable in critically ill COVID-19 patients ${ }^{12-15}$.

A clinically usable test design is exemplified by assays to measure T-cell response to cytomegalovirus (CMV). These assays use unselected peptide mixtures representing the entire antigenic sequence of interest, a single activation marker, and no costimulators ${ }^{18-20}$. Here, we describe a minimal marker assay to characterize S-reactive T- and B-cells in healthy unexposed subjects and COVID-19 patients most of whom were hospitalized, with an emphasis on chronically immunosuppressed solid organ transplant recipients. A sizeable cohort of NT subjects is also included to enable robust conclusions and comparisons.

Results: Human Subjects: Of 204 total subjects, 101 were healthy subjects, H-Tr or H-NT, and 103 had been recently diagnosed with COVID-19, Tr or NT. The 204 subjects included $74 \mathrm{Tr}$ recipients, of whom 42 were sampled pre-pandemic in 2019 or earlier, and 32 had COVID-19 infection. Of 130 NT subjects, 59 were H-NT subjects of whom twenty-five were sampled prepandemic and thirty-four were negative for COVID-19 by antibody testing. Seventy-one NT subjects had COVID-19 infection. Compared with healthy unexposed subjects, COVID-19 patients were predominantly non-Caucasian (38/101 vs 83/103 non-Caucasians, $p<0.001)$ males (47/101 vs $60 / 103$ males, $p=N S$ ) and were significantly older (41 vs 54 years, $p=7.7 E-06)$. General demographics for all 204 subjects are summarized in Table 1. Details including treatment and outcomes for COVID-19 patients are shown in Table S1. 


\section{SARS2-specific CD154-expressing T- and B-cells co-express IFN/ and interleukin-6 (IL-6):}

Stimulation of PBL from three healthy-NT with S peptides, cell permeabilization and ICS with specific fluorochrome-labeled detector antibodies showed that S-reactive T-cells which expressed CD154 also expressed IFN $\gamma$, a marker of cytotoxic T-cells (Figure 1a). Further, CD154 was also co-expressed with IL-6 in B-cells (Figure 1b). Thus, CD154 was used as a surrogate for S-reactive IFN $\gamma+$ T-cells, and S-reactive IL-6+B-cells in all subsequent assays using nonpermeabilizing CD154 staining described previously ${ }^{18,21}$.

Reproducibility: S-reactive CD154-expressing CD3, CD4, CD8 and CD19 cells were measured in duplicate assays performed on the same day, before and after 7 days of cryopreservation in liquid nitrogen, and before and after overnight storage or overnight shipment at ambient temperature. Mean coefficient of variation between duplicate assays was $2-10.6 \%$ in these various conditions (Tables S2-S5).

\section{T- and B-cell responses to spike antigens are impaired with COVID-19 infection and} increasing disease severity. Frequencies of S-reactive CD3, CD4, CD8 and CD19 B-cells were lower in 32 Tr recipients with COVID-19 compared with $42 \mathrm{H}-\mathrm{Tr}$ recipients $(p<0.001)$ (Figure 2ab, Table S6). S-reactive CD3 and S-reactive CD8 cell frequencies decreased progressively with increasing COVID-19 severity in Tr patients with COVID-19 infection. This decrease achieved significance for hospitalized recipients and those with severe COVID-19, compared with healthyTr subjects (Figure 2c-d). S-reactive T-cell frequencies in Tr patients with mild COVID-19 infection were similar to those in healthy-Tr recipients.

These differences were not seen in NT patients with COVID-19 compared with healthy-NT subjects. The sole exception consisted of lower S-reactive CD3 cells in NT patients with COVID19, compared with healthy-NT subjects, $p=0.045$ (Figure 2e-f). 
Impaired antibody response to RBD in COVID-19 transplant patients. Of 74 COVID-19 patients with antibody measurements, 51 received convalescent plasma. IgG to spike antigen and RBD antigen were present in 49 of 51 (96\%) and 47 of 51 (92\%) patients, respectively. Among the remaining 23 patients who did not receive convalescent plasma, IgG to spike and RBD antigens were present in 21 (91\%) and 16 (69.5\%) patients, respectively. The incidence of antiRBD IgG was significantly lower in transplant patients with COVID-19, 2 of 7 or $29 \%$, compared with non-transplant patients, 14 of 16 or $88 \%(p=0.011)$ (Figure 3a). No differences were seen in the incidence of anti-spike lgG (5/7 or $71 \%$ vs $16 / 16$ or $100 \%, p=N S)$ (Figure $3 b)$. Subjects without and with anti-RBD antibody did not differ in timing of the sample from diagnosis (mean+/-SD 18+/12.5 vs $12+/-12, p=0.258$, NS, respectively), frequencies of S-reactive T-cells (mean $3.1+/-2.4 \%$ vs $1.8+/ 2 \%, p=0.225$, NS, respectively), or proportions of patients requiring intubation ( $2 / 7$ or $29 \%$ vs $4 / 16$ or $25 \%, p=1.00$, NS, respectively. S-reactive B-cell frequencies were also significantly lower in Tr and NT patients with COVID-19, compared with corresponding healthy subjects (Figure 3c).

Increased risk of CMV co-infection in transplant recipients: Of 32 Tr recipients with COVID19, 11 (34\%) experienced CMV infection-10 had CMV viremia and one had CMV hepatitis. Consistent with this increased risk in Tr patients, CMV infection was associated with decreased T-cell immunity to this virus in Tr patients with COVID-19. Frequencies of CMV-specific T-cells which express CD154 after stimulation with the pp65 antigenic peptide mixture were measured as described previously, in 61 subjects $^{18}$. CMV-specific T-cell frequencies were significantly lower in $16 \operatorname{Tr}$ recipients with COVID-19 compared with 13 healthy $\operatorname{Tr}$ recipients $(0.5+/-0.4 \%$ vs $1.5+/-$ $0.5 \%, p=3 E-05$, Figure 4a). CMV-specific T-cell frequencies were not significantly different between 6 NT subjects without and 26 NT subjects with COVID-19 ( $p=0.21$, NS, Figure 4b). CMV infection did not occur in NT patients with COVID-19. 


\section{Increased circulating myeloid-derived suppressor cells (MDSC) during COVID-19 infection.}

Twenty-four healthy and 29 COVID-19 patients were tested for circulating MDSCs. COVID-19 patients demonstrated higher frequencies of monocytic or M-MDSC (CD14+HLA-DR $)$ compared with healthy subjects (Median \pm SEM, $39 \pm 7.8 \%$ vs $2.95 \pm 1.1 \%, p=9.8 \mathrm{E}-08$ ) (Figure 4c). MMDSC frequencies correlated negatively with S-reactive T-cell frequencies (Spearman's $r=$ 0.276, $p=0.045$ Figure 4d). Polymorphonuclear or P-MDSC (CD15+CD14-CD11b+) frequencies were also higher in four COVID-19 subjects compared with 22 healthy subjects (median \pm SEM, $64.2 \pm 19.4 \%$ vs $1.25 \pm 1.4 \%, p=0.059, N S$ ), and were negatively correlated with S-reactive Tcell frequencies (Spearman's $r=-0.518, p=0.007$ ).

Discussion: Our study found that S-reactive T-cells are present in pre-pandemic PBL samples from chronically immunosuppressed transplanted (Tr) recipients. This type of pre-existing T-cell immunity has been reported previously in the general population and is also seen in our study population of healthy NT subjects ${ }^{12-15}$. Experimental evidence from previous studies implicates prior exposure to structurally similar human coronaviruses, which cause seasonal flu ${ }^{16-17}$. We speculate that this explanation also applies to our $\operatorname{Tr}$ recipient cohort. Unlike some previous studies, however, we observed lower S-reactive T-cell frequencies in COVID-19 patients compared with healthy unexposed individuals. This decrease was significant and most pronounced for $\operatorname{Tr}$ patients with COVID-19 compared with controls (Figure 2b-d). Further, compared with healthy-Tr subjects, $\operatorname{Tr}$ patients with COVID-19 infection also demonstrated a progressive decline in S-reactive T-cell frequencies with increasing disease severity, from hospitalization $(p<0.05)$ to severe disease requiring intubation $(p<0.0001)$. S-reactive T-cell frequencies in Tr patients with mild symptoms were in the same range as healthy unexposed $\mathrm{Tr}$ subjects $(p=N S)$. These differences were also observed for S-reactive CD8 cells among $\mathrm{Tr}$ patients with COVID-19 (Figure 2d). Among NT patients with COVID-19, the decrease in S- 
reactive CD3 cell frequencies arose from those with severe COVID-19 infection (Figure 2e). No other between-group differences were identified for NT subjects.

Unlike previous studies, the majority of our COVID-19 patients, 91 of 103, were hospitalized, 58 without and 33 with severe disease requiring intubation for respiratory failure. This distribution represents a more severely affected infection cohort and may explain lower mean T-cell frequencies in infected patients compared with those who were healthy. Loss of T-cell immunity to the virus has been observed in critically ill patients in some previous studies ${ }^{12}$. Previous reports have also shown higher S-reactive T-cell frequencies in convalescent patients compared with unexposed subjects ${ }^{12-15}$. These higher responses may be unique to the convalescent phase. Another reason for the higher T-cell responses in COVID-19 infection in some previous studies may be the use of peptides with high affinity for selected HLA specificities, with or without adjunctive co-stimulators. This approach may have elicited larger T-cell responses from memory subsets. Our study patients were sampled at an average interval of 12 days after diagnosis of COVID-19 and assayed using unselected peptide stimulators, without adjunctive co-stimulators.

In previous studies, S-reactive T-cell frequencies averaging $<1 \%$ have been observed in healthy unexposed subjects, compared with roughly $3 \%$ in our studies ${ }^{12-15}$. Some of these studies counted S-reactive T-cells as those that co-expressed marker combinations like CD137 and CD69, but excluded S-reactive T-cells that expressed either marker alone ${ }^{12,13}$. We have modeled our assay on clinical assays which measure antiviral T-cell immunity by employing a single marker. These assays use either IFN $\gamma$ or CD154 as a marker of antigen-specific T-cells ${ }^{18-20,22,23}$. CD154 can substitute for IFN $\gamma$ because it is co-expressed in viral antigen-specific T-cells ${ }^{18,24}$. As a single marker of antigen-specific T-cells, CD154 can also be detected with non-permeabilizing methods. Alloantigen-specific T-cytotoxic memory cells that express CD154 have met criteria for regulatory 
approval to predict transplant rejection ${ }^{25}$. S-reactive T-cell frequencies averaging $3 \%$ in our healthy unexposed subjects have also been observed among proliferating S-reactive T-cells in a previous study ${ }^{14}$. We cannot fully explain higher average frequencies in healthy unexposed $\mathrm{Tr}$ compared with NT subjects (mean 3.1 vs $4.2 \%, p=0.042$, Table S6). However, extended ex vivo exposure of normal human PBL to pro-apoptotic anti-lymphocyte antibodies enriches apoptosisresistant alloantigen-reactive CD154+T-cells among surviving $\mathrm{PBL}^{26}$. Thus, it is possible that exposure of T-cells to chronic immunosuppression may have contributed to an enrichment of Sreactive T-cells in PBL from Tr recipients.

The Tr recipient cohort with COVID-19 was noteworthy for CMV co-infection presenting as viremia in 10 , and CMV hepatitis in one recipient for an incidence of 11 of 32 or $34 \%$. CMV infection occurred at a median of 22 days (range 1-104 days) after diagnosis of COVID-19 infection. Transplant recipients with COVID-19 also demonstrated lower frequencies of CMV-specific Tcells compared with NT COVID-19 patients, $0.4 \pm 0.1$ vs $0.85 \pm 0.24, p=0.0048$. Consistent with a lack of such differences in NT subjects, no CMV co-infections were reported in NT patients with COVID-19.

Of great interest is the observation that Tr recipients also demonstrated a lower incidence of IgG antibodies to the RBD component of the S protein after COVID-19 infection compared with NT recipients, 2 of 7 vs 3 of $16, p=0.011$. The incidence of anti-S IgG antibodies was similar between the T and NT groups. The RBD sequence is a component of the less conserved N-terminal S1 sequence of the SARS-CoV-2 spike protein. The S1 protein has $60 \%$ sequence similarity to hCoV. As such, the RBD sequence may be less immunogenic when presented to the host immune system for the first time, compared with the more conserved C-terminal S2 sequence, which has $80 \%$ homology with hCoV. Test positivity was based on an $\mathrm{OD}_{490}$ of 0.45 or greater in the ELISA antibody binding assay. The amount of $\lg G$ antibody reflected by $\mathrm{OD}_{490}$ readings was also lower 
in Tr compared with NT patients for anti-spike $\lg G(p=0.16, N S)$ achieving significance for antiRBD IgG ( $<<0.001)$ (Figure 3). Impaired antibody responses to natural COVID-19 infection in $\mathrm{Tr}$ recipients may augur impaired antibody responses to COVID-19 vaccines in this population.

Suppressed cellular and antibody responses in Tr recipients may have other reasons. Recent studies have revealed increased circulating myeloid derived suppressor cells (MDSC), pyroptotic cell death and lymphopenia in COVID-19 patients ${ }^{27-31}$. MDSC are myeloid progenitors that expand in peripheral blood in response to lymphopenia and are known to suppress T-cells. Frequencies of monocytic and polymorphonuclear MDSC were higher in COVID-19 patients compared with healthy unexposed subjects. The corresponding decrease in S-reactive T-cells is reflected in significant negative correlations between S-reactive T-cells and MDSC.

In conclusion, transplant recipients demonstrate pre-existing T-cell immunity to SARS-CoV-2 in a manner similar to the general population. Unique attributes of COVID-19 infection in transplant recipients include a) impaired T-cell immunity to SARS-CoV-2, to the greatest degree in those with increasing disease-severity, b) increased risk for CMV co-infection, and c) impaired antibody responses. Surveillance of CMV viral loads during COVID-19 infection, and post-vaccination surveillance of antibody responses to confirm vaccine efficacy may be necessary in transplant recipients.

Methods: Human Subjects: COVID-19 patients were enrolled under IRB-approved protocols 2017-0365, Pro00101915, and 1551551 respectively, at three centers in Washington, DC, Charleston, SC, and Edinburg, TX, respectively. De-identified residual cryopreserved PBL samples were tested under IRB-exempt protocol, and samples from healthy-NT subjects were tested under IRB approved protocol 6774 in the reference laboratory (Plexision, Pittsburgh, PA). Healthy unexposed subjects, $\mathrm{H}-\mathrm{NT}$ and $\mathrm{H}$-Tr were tested using samples that were either obtained 
pre-pandemic, in 2019 or earlier, or were tested after confirming absence of symptoms suggestive of flu-like symptoms in the 6-month period prior to testing and a negative test for $\lg G$ to $S$ and RBD antigens. COVID-19 patients, Tr or NT, were tested with samples obtained after confirmation of diagnosis with PCR.

Measuring SARS-CoV-2-reactive T-cell and B-cell subsets: All PBL samples were cultured alone (background), with 315 15-mer overlapping peptides with 11-mer overlap representing the 1273 amino acid spike antigen (test reaction), and with phorbol-myristic acid-Calcium ionophor (PMA, positive control) for 16 hours at $37^{\circ} \mathrm{C}$ in $5 \% \mathrm{CO} 2$ incubator. The peptide mixture consisted of two components mixed in equal parts-158 peptides representing the less conserved $\mathrm{N}$-terminal sequence, S1, and 157 peptides representing the more conserved C-terminal sequence, S2, of the spike protein (JPT Peptides, Berlin, Germany). The S1 and S2 sequences respectively have $64 \%$ and $90 \%$ sequence homology with the SARS virus ${ }^{32}$. The culture medium contained fluorochrome-labeled antibody to CD154 (catalog \#563886, BD Biosciences, San Jose, CA). Cells were acquired on the FACS-Canto II flow cytometer with blue, red and violet lasers after addition of fluorochrome labeled antibodies to CD3, CD4, CD8, and CD19 and the viability dye 7aminoactinomycin-D (catalog \#s 340662, 641407, 340692, 341103, 559925, respectively, BD Biosciences, San Jose, CA). The gating strategy is shown in Figure S1. Scatterplots acquired from assay reaction conditions for CD3, CD4, CD8 and CD19 cells are shown in Figure S2. Frequencies for each subset which were reactive to the S peptide mixture were analyzed further after subtracting corresponding background frequencies.

CMV- and mitogen-reactive T-cells: Previously described methods were used to measure frequencies of CMV- specific T-cells and mitogen-reactive T-cells that expressed CD154 in response to stimulation with the pp65-CMV antigen and PMA, respectively ${ }^{18}$. 
Serological assay to detect SARS-CoV-2 antibody: 96-well microtiter plates were coated overnight at $4^{\circ} \mathrm{C}$ with commercially available S-protein (Cat \# 46328, LakePharma, San Carlos, $\mathrm{CA}$,) at $2 \mathrm{ug} / \mathrm{ml}$, and blocked for $1 \mathrm{hr}$ with PBS-Tween $+3 \%$ milk powder (weight/volume). Precoated wells were incubated with diluted samples for 2 hours, followed by anti-human IgG (Fab specific) HRP labeled secondary antibody 1:3000 in PBS-T containing 1\% milk for 1 hour. After adding substrate (OPD solution), followed by $50 \mu \mathrm{l}$ of $3 \mathrm{M}$ hydrochloric acid to stop the reaction, plates were read at $490 \mathrm{~nm}$ on a spectrophotometer. With all samples, inactivated human $A B$ serum was used as a negative control, while monoclonal antibody CR3022 was used as a positive control. Results were read on a plate reader as optical density at $490 \mathrm{~nm}$. An optical density of 0.45 or greater was considered a positive test as reported earlier ${ }^{33}$.

Myeloid-derived suppressor cells (MDSC): MDSC represent early lineage cells that cause Tcell suppression and develop in response to lymphopenia and the inflammatory response to the viral infection ${ }^{34-36}$. Fluorochrome-labeled antibodies to the respective markers for each cell were used to characterize monocytic- and polymorphonuclear-MDSC (M-MDSC and P-MDSC). The respective phenotypes were CD14+HLADR- and CD15+CD14-CD11b+ ${ }^{36}$. Antibodies used were from Biolegend (Cat \# 307618,301906,301306, San Diego, CA) or BD Biosciences (Cat \# 563743, San Jose, CA).

Statistical methods: Descriptive statistics were used to summarize group features. Between group comparisons were performed with t-tests for unadjusted data and linear models to adjust for demographic variables.

Acknowledgements: NSF\#2033307 (CA, Plexision), NIH Grant number UL1 TR001450 (MUSC), intramural support from all participating institutions and Plexision. 
Disclosure: University of Pittsburgh Patent 9606019, author: RS, describes CMI testing for CMV, is licensed exclusively to Plexision, in which University and RS own equity. RS and CA developed Plexision's patent-pending multi-variate CMI assay for SARS2. RS is Professor of Surgery at the University of Pittsburgh and Chief Scientific Officer of Plexision by permission of Conflict of Interest committee at the University. $\mathrm{CA}$ and $\mathrm{BH}$ are paid consultants to Plexision. Other authors have nothing to disclose.

Data Availability Statement: All data that underlie the results reported in this Article (including study protocol) on individual participants will be made available to researchers who provide a methodologically sound proposal to the corresponding author.

Contributors and Data Management: RV, AHK, JA, GM, SN, SR, HD, KK, MMBC, KS, GB, AK, MN, PB, TF HD, KK recruited subjects, interpreted results, wrote and edited manuscript. SN and SM performed, interpreted and described antibody testing. CA performed and described CMI assays for SARS2 antigens on de-identified samples. BS, MS, NA and ES compiled, crosschecked, tabulated, summarized and described cell counts and frequency data. Demographics of de-identified subjects were summarized by BS who also performed and described CMI assays for CMV. Cytometry results and demographics were verified by PS, and transmitted to statistician BWH who merged the two datasets, performed all analyses and returned results and descriptions of analyses to PS and wrote and edited manuscript. KM and SS confirmed results of logistic regression with alternative linear models, edited and wrote manuscript. PS interpreted study results and relayed interpretations to $\mathrm{RS}$ for communication to all investigators. RS conceived the study, coordinated with centers and investigators, incorporated descriptions from other authors, wrote and edited manuscript with all authors. 


\section{Reference:}

1. Boyarsky BJ, Werbel WA, Avery RK, et al. Immunogenicity of a Single Dose of SARSCoV-2 Messenger RNA Vaccine in Solid Organ Transplant Recipients. JAMA. Published online March 15, 2021. doi:10.1001/jama.2021.4385

2. Akalin E, Azzi Y, Bartash R, et al. Covid-19 and Kidney Transplantation. N Engl J Med. 2020 Jun 18;382(25):2475-77. doi: 10.1056/NEJMc2011117. Epub 2020 Apr 24.

3. Choi M, Bachmann F, Naik MG, et al Low Seroprevalence of SARS-CoV-2 Antibodies during Systematic Antibody Screening and Serum Responses in Patients after COVID-19 in a German Transplant Center. J Clin Med. 2020 Oct 23;9(11):3401. doi: 10.3390/jcm9113401. PMID: 33114149; PMCID: PMC7690804.

4. Jackson LA, Anderson EJ, Rouphael NG, et al. An mRNA Vaccine against SARSCoV-2 - Preliminary Report. N Engl J Med. 2020 Nov 12;383(20):1920-1931. doi: 10.1056/NEJMoa2022483. Epub 2020 Jul 14. PMID: 32663912; PMCID: PMC7377258.

5. Mulligan MJ, Lyke KE, Kitchin N, et al. Phase I/II study of COVID-19 RNA vaccine BNT162b1 in adults. Nature. 2020 Oct;586(7830):589-593. doi: 10.1038/s41586-0202639-4. Epub 2020 Aug 12. Erratum in: Nature. 2021 Feb;590(7844):E26. PMID: 32785213.

6. Folegatti PM, Ewer KJ, Aley PK, et al. Safety and immunogenicity of the ChAdOx1 nCoV-19 vaccine against SARS-CoV-2: a preliminary report of a phase $1 / 2$, singleblind, randomised controlled trial. Lancet August 15, 2020. 396:467-78.

7. Polack FP, Thomas SJ, Kitchin N, et al. Safety and Efficacy of the BNT162b2 mRNA Covid-19 Vaccine. N Engl J Med. 2020 Dec 31;383(27):2603-2615. doi: 10.1056/NEJMoa2034577. Epub 2020 Dec 10. PMID: 33301246; PMCID: PMC7745181.

8. Baden LR, El Sahly HM, Essink B, et al. Efficacy and Safety of the mRNA-1273 SARSCoV-2 Vaccine. N Engl J Med. 2021 Feb 4;384(5):403-416. doi: 10.1056/NEJMoa2035389. Epub 2020 Dec 30. PMID: 33378609; PMCID: PMC7787219.

9. Anderson EJ, Rouphael NG, Widge AT, et al. Safety and Immunogenicity of SARSCoV-2 mRNA-1273 Vaccine in Older Adults. N Engl J Med. 2020 Dec 17;383(25):2427-2438. doi: 10.1056/NEJMoa2028436. Epub 2020 Sep 29. PMID: 32991794; PMCID: PMC7556339.

10. Choe, P., Kim, K., Kang, C., Suh, H., Kang, E., Lee, S....Oh, M. (2021). Antibody Responses 8 Months after Asymptomatic or Mild SARS-CoV-2 Infection. Emerging Infectious Diseases, 27(3), 928-931. https://dx.doi.org/10.3201/eid2703.204543.

11. Hartley GE, Edwards ESJ, Aui PM, Varese N, Stojanovic S, McMahon J, Peleg AY, Boo I, Drummer HE, Hogarth PM, O'Hehir RE, van Zelm MC. Rapid generation of durable B cell memory to SARS-CoV-2 spike and nucleocapsid proteins in COVID19 and convalescence. Sci Immunol. 2020 Dec 22;5(54):eabf8891. doi: 10.1126/sciimmunol.abf8891. PMID: 33443036; PMCID: PMC7877496.

12. Braun J, Loyal L, Frentsch M, Wendisch D, et al. SARS-CoV-2-reactive T cells in healthy donors and patients with COVID-19. Nature. 2020 Nov;587(7833):270-274. doi: 10.1038/s41586-020-2598-9. Epub 2020 Jul 29. PMID: 32726801.

13. Grifoni A, Weiskopf D, Ramirez SI, et al. Targets of T Cell Responses to SARS-CoV2 Coronavirus in Humans with COVID-19 Disease and Unexposed Individuals. Cell 2020;181:1489-501 e15.

14. Sekine T, Perez-Potti A, Rivera-Ballesteros O, et al. Robust $T$ Cell Immunity in Convalescent Individuals with Asymptomatic or Mild COVID-19. Cell. 2020 Oct 
1;183(1):158-168.e14. doi: 10.1016/j.cell.2020.08.017. Epub 2020 Aug 14. PMID: 32979941 ; PMCID: PMC7427556.

15. Le Bert N, Tan AT, Kunasegaran K, et al. SARS-CoV-2-specific T cell immunity in cases of COVID-19 and SARS, and uninfected controls. Nature July 2020. 10.1038/s41586-020-2550-z

16. Kahn JS, Mclntosh K. History and recent advances in coronavirus discovery. Pediatr Infect Dis J. 2005 Nov;24(11 Suppl):S223-7, discussion S226. doi:

10.1097/01.inf.0000188166.17324.60. PMID: 16378050.

17. Woldemeskel BA, Kwaa AK, Garliss CC, Laeyendecker O, Ray SC, Blankson JN. Healthy donor T cell responses to common cold coronaviruses and SARS-CoV-2. J Clin Invest. 2020 Dec 1;130(12):6631-6638. doi: 10.1172/JCl143120. PMID: 32966269; PMCID: PMC7685719.

18. Ashokkumar C, Green M, Soltys K, et al. CD154-expressing CMV-specific T cells associate with freedom from DNAemia and may be protective in seronegative recipients after liver or intestine transplantation. Pediatr Transplant 2020;24:e13601. 10.1111/petr.13601.

19. Kumar D, Chin-Hong P, Kayler L, Wojciechowski D, Limaye AP, Osama Gaber A, Ball S, Mehta AK, Cooper M, Blanchard T, MacDougall J, Kotton CN. A prospective multicenter observational study of cell-mediated immunity as a predictor for cytomegalovirus infection in kidney transplant recipients. Am J Transplant. 2019 Sep;19(9):2505-2516. doi: 10.1111/ajt.15315. Epub 2019 Mar 15. PMID: 30768834.

20. Rego K, Pereira K, MacDougall J, Cruikshank W. Utility of the T-SPOT®.TB test's borderline category to increase test resolution for results around the cut-off point. Tuberculosis. 2018;108:178-185. doi:10.1016/j.tube.2017.12.005.

21. Ashokkumar C, Soltys K, Mazariegos G, et al. Predicting Cellular Rejection With a Cell-Based Assay: Preclinical Evaluation in Children. Transplantation. 2017;101(1):131-140. doi:10.1097/TP.0000000000001076

22. Mazurek GH, Jereb J, Vernon A, LoBue P, Goldberg S, Castro K, IGRA Expert Committee, Centers for Disease Control and Prevention (CDC). Updated guidelines for using Interferon Gamma Release Assays to detect Mycobacterium tuberculosis infection - United States, 2010. MMWR Recomm Rep. 2010;59(RR-5):1-25.

23. King TC, Upfal M, Gottlieb A, Adamo P, Bernacki E, Kadlecek CP, Jones JG, Humphrey-Carothers F, Rielly AF, Drewry P, Murray K, DeWitt M, Matsubara J, O'Dea L, Balser J, Wrighton-Smith P. T-SPOT.TB Interferon-y Release Assay Performance in Healthcare Worker Screening at Nineteen U.S. Hospitals. Am J Respir Crit Care Med. 2015;192(3):367-373. doi:10.1164/rccm.201501-01990C.

24. Chattopadhyay $\mathrm{PK}, \mathrm{Yu} \mathrm{J}$, Roederer M. A live-cell assay to detect antigen-specific CD4+ T cells with diverse cytokine profiles. Nat Med. 2005 Oct;11(10):1113-7. doi: 10.1038/nm1293. Epub 2005 Sep 25. PMID: 16186817.

25. FDA U.S. Food and Drug Administration. Recently-Approved Devices. https://www.accessdata.fda.gov/scripts/cdrh/cfdocs/cfhde/hde.cfm?id=H130 $\underline{004}$

26. Ashokkumar C, Sun Q, Ningappa M, Higgs BW, Mazariegos G, Zeevi A, Sindhi R. Antithymocyte globulin facilitates alloreactive T-cell apoptosis by means of caspase3: potential implications for monitoring rejection-free outcomes. Transplantation. 2015 Jan;99(1):164-70. doi: 10.1097/TP.0000000000000289. PMID: 25531894; PMCID: PMC4274752.

27. Schulte-Schrepping J, Reusch N, et al. Severe COVID-19 is marked by a dysregulated myeloid cell compartment. Cell. 2020;182:1419-1440. https://doi.org/10.1016/j.cell.coco.08.001. 
28. Agrati C, Sacchi A, Bordoni V, et al. Expansion of myeloid-derived suppressor cells in patients with severe coronavirus disease (COVID-19). Cell Death Differ. 2020;1-12.

29. Schulte-Schrepping J, Reusch N, Paclik D, et al. Severe COVID-19 is marked by a dysregulated myeloid cell compartment. Cell. 2020;182(6):1419-40.

30. Feng S, Cheng X, Zhang L, et al. Myeloid-derived suppressor cells inhibit $T$ cell activation through nitrating LCK in mouse cancers. Proc Natl Acad Sci. 2018;115(40):10094-9.

31. Kroemer A, Khan K, Plassmeyer M, Alpan O, Haseeb MA, Gupta R, Fishbein TM. Inflammasome activation and pyroptosis in lymphopenic liver patients with COVID-19. J Hepatol. 2020 Nov;73(5):1258-1262. doi: 10.1016/j.jhep.2020.06.034. Epub 2020 Jul 6. PMID: 32645361; PMCID: PMC7336919.

32. Jaimes JA, Andre NM, Chappie JS, Millet JK, Whittaker GR. Phylogenetic Analysis and Structural Modeling of SARS-CoV-2 Spike Protein Reveals an Evolutionary Distinct and Proteolytically Sensitive Activation Loop. J Mol Biol 2020 May 1;432(10):3309-3325. doi: 10.1016/j.jmb.2020.04.009. Epub 2020 Apr 19.

33. Xu G, Emanuel AJ, Nadig S, Mehrotra S, Caddell BA, Curry SR, Nolte FS, Babic N. Evaluation of Orthogonal Testing Algorithm for Detection of SARS-CoV-2 IgG Antibodies. Clin Chem. 2020 Sep 7:hvaa210. doi: 10.1093/clinchem/hvaa210. Epub ahead of print. PMID: 32894753; PMCID: PMC7499512.

34. O'Connor, Megan A et al. "The Role of Myeloid-Derived Suppressor Cells in Viral Infection." Viral immunology vol. 30,2 (2017): 82-97. doi:10.1089/vim.2016.0125

35. Gabrilovich DI. Myeloid-Derived Suppressor Cells. Cancer Immunol Res. 2017 Jan;5(1):3-8. doi: 10.1158/2326-6066.CIR-16-0297. PMID: 28052991; PMCID: PMC5426480.

36. Bronte, V., Brandau, S., Chen, SH. et al. Recommendations for myeloid-derived suppressor cell nomenclature and characterization standards. Nat Commun 7, 12150 (2016). 


\section{Figure legends:}

Figure 1. Flow cytometry scatterplots show a) expression of CD154 and IFN $\gamma$ in S-reactive and PMA-reactive T-cells, and (b) expression of CD154 and IL-6 in S-reactive and PMA-reactive Bcells. $P M A=$ phorbol-myristic acid, a mitogen.

Figure 2. a. Flow cytometry scatterplots S-reactive CD3 cells in a representative healthytransplant, healthy-non-transplant, Mild COVID-19, COVID-19 hospitalized, and COVID-19 subject intubated for mechanical ventilation. b. Dot plots show frequencies of S-reactive T-cells (CD3) in healthy-transplant (H-Tr), COVID-19-transplant (Tr), healthy-non-transplant (H-NT) and COVID-19 non-transplant (NT) subjects. c-f. Dot plots show frequencies of S-reactive CD3 cells (c, e) and CD8 cells (d, f) in transplant (c, d) and non-transplant patients (e, f) with COVID-19 who have mild infection treated as outpatient, or are hospitalized or have severe infection. Corresponding frequencies from healthy transplant and non-transplant subjects are shown in each dot plot ( ${ }^{*}$ represents p:value $\left.<0.05\right)$.

Figure 3. Optical density at $490 \mathrm{~nm}\left(\mathrm{OD}_{490}\right)$ for (a) Anti-RBD lgG and (b) Anti-spike IgG in transplant (Tr) and non-transplant (NT) patients with COVID-19 infection. Dotted lines show the $\mathrm{OD}_{490}$ cutoff of 0.45 above which the tests are deemed positive. (c) S-reactive B-cell frequencies in healthy-NT, healthy-T and T and NT patients with COVID-19 Infection. ( ${ }^{*}$ represents p:value $<0.05)$.

Figure 4. a. Dot plot shows CMV-specific T-cell frequencies among healthy transplant $(\mathrm{H}-\mathrm{Tr})$, healthy non-transplant (HNT), and COVID-19 patients with transplant (Tr) and without transplant (NT). b. frequencies of monocytic myeloid-derived suppressor cells (MDSC) in healthy unexposed 
subjects and COVID-19 patients. c. Correlation between frequencies of S-reactive CD154+T-cells and monocytic MDSC. ( ${ }^{*}$ represents p:value $\left.<0.05\right)$.

\section{Supplementary Figure Legends:}

Figure S1. Flow cytometric gating strategy shows derivation of CD3 ${ }^{+}$T-cells and CD19+ B-cells from the lymphocyte population. CD4 and CD8 T-cells were than gated from $\mathrm{CD}^{+} \mathrm{T}^{+}$-cells. Scatterplots show CD3, CD4, CD8 and CD19 cells that express CD154 when incubated alone (background), with spike antigen (test reaction) and PMA - Calcium ionophore (positive control). The negative control reaction shows autofluorescence in the absence of fluorochrome-labeled CD154 antibody. 
Table 1: General demographics of the study population.

Abbreviations: H-Tr: Healthy transplant, H-NT: healthy non-transplant, Tr-transplant recipients with COVID-19, NT-nontransplant patient with COVID-19, C: Caucasian, AA: African American, H: Hispanic, A: Asian, L: Liver transplant, K: Kidney transplant and LK: Liver-Kidney Transplant, Intub: Intubation, Hosp: Hospitalized, Mild: Mild.

\begin{tabular}{|c|c|c|c|c|c|c|c|c|}
\hline \multirow[b]{2}{*}{$\mathbf{N}$} & \multirow{2}{*}{$\begin{array}{c}\text { H-NT } \\
59\end{array}$} & \multirow{2}{*}{$\begin{array}{c}\text { H-Tr } \\
42\end{array}$} & \multirow{2}{*}{$\begin{array}{l}\text { NT } \\
71\end{array}$} & \multirow{2}{*}{$\begin{array}{c}\mathrm{Tr} \\
32\end{array}$} & \multicolumn{4}{|c|}{ p value } \\
\hline & & & & & $\begin{array}{c}\text { H-NT vs } \\
\text { H-Tr }\end{array}$ & NT vs Tr & H-NT vs NT & H-Tr vs Tr \\
\hline Age (Years) & $44 \pm 2.1$ & $43 \pm 3.9$ & $57 \pm 2.0$ & $\begin{array}{c}51.1 \pm \\
4.0\end{array}$ & NS & NS & 1.97E-05 & NS \\
\hline Age range & $18-78$ & $1.5-70.2$ & $24-87$ & $0.56-77$ & & & & \\
\hline Male: Female & $22: 37$ & $25: 17$ & $39: 32$ & $21: 11$ & NS & NS & NS & NS \\
\hline $\begin{array}{c}\text { Race } \\
\text { (C:AA:H:A) }\end{array}$ & $37: 9: 0: 13$ & $26: 13: 2: 1$ & $12: 4: 54: 1$ & $8: 11: 11: 2$ & NS & 0.0348 & $3.15 E-05$ & 0.0003 \\
\hline Organ (L:K:LK) & NA & $25: 17: 0$ & NA & $21: 9: 2$ & NA & NA & NA & NS \\
\hline Alive:Dead & $59: 0$ & $42: 0$ & $67: 4$ & $27: 5$ & NA & NS & NA & NA \\
\hline \multirow{2}{*}{$\begin{array}{c}\text { Disease Severity } \\
\text { (Intub:Hosp:Mild) } \\
\text { Convalescent } \\
\text { Plasma }\end{array}$} & NA & NA & $21: 40: 10$ & 12:18:2 & NA & NS & NA & NA \\
\hline & NA & NA & 50 & 4 & NA & 0.0001 & NA & NA \\
\hline
\end{tabular}



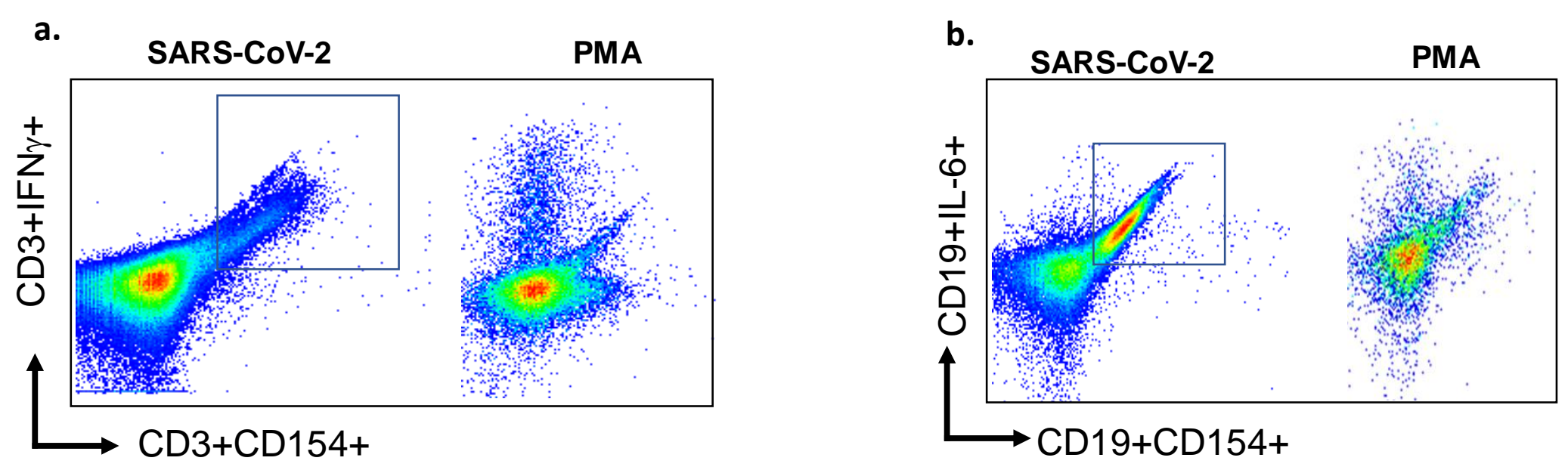
Figure 2:

a.

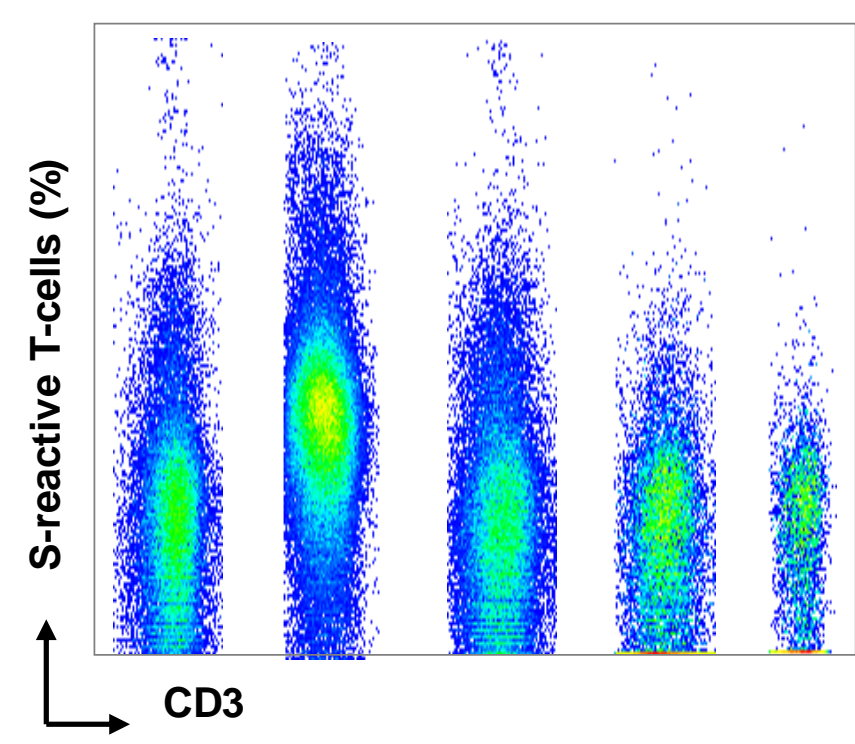

b.

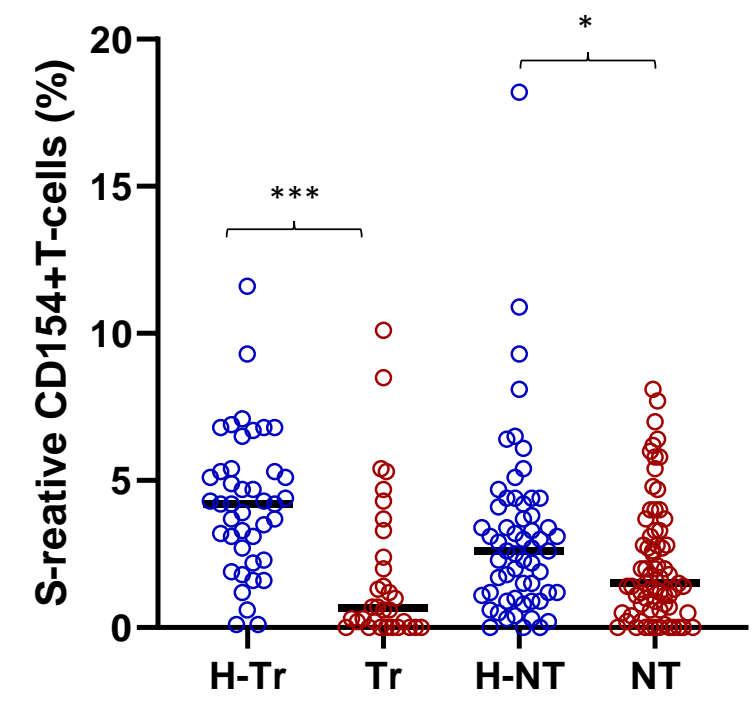

c.

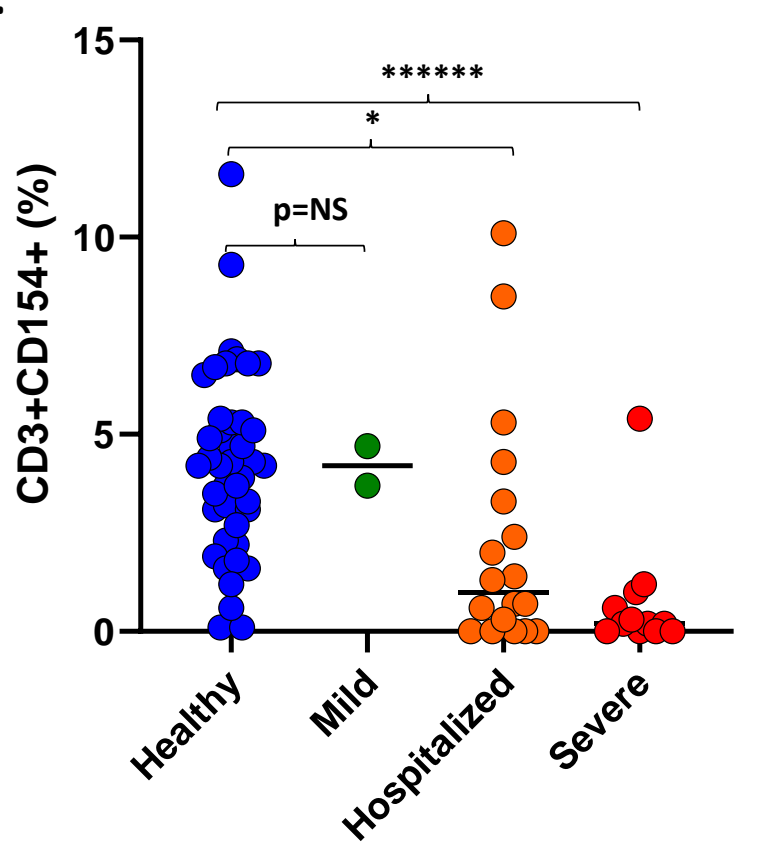

d.

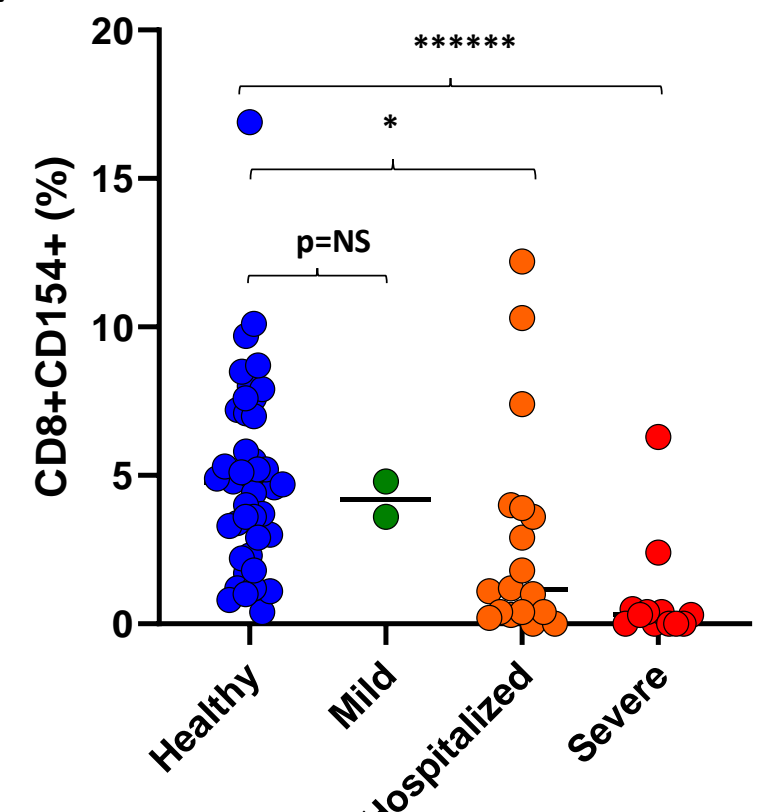

Non-transplant

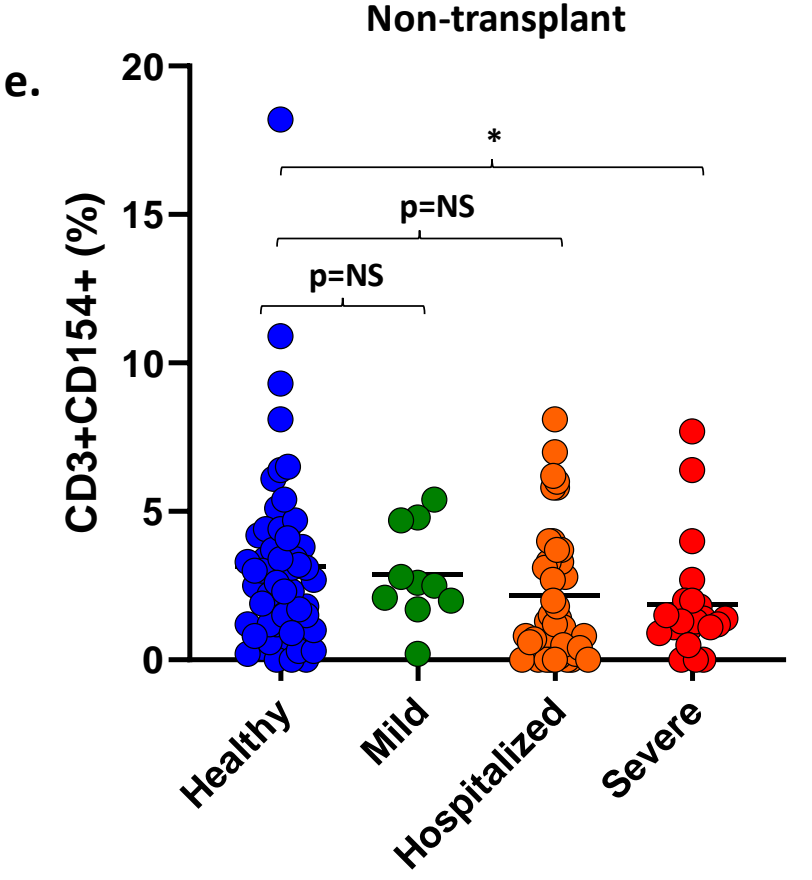

f.

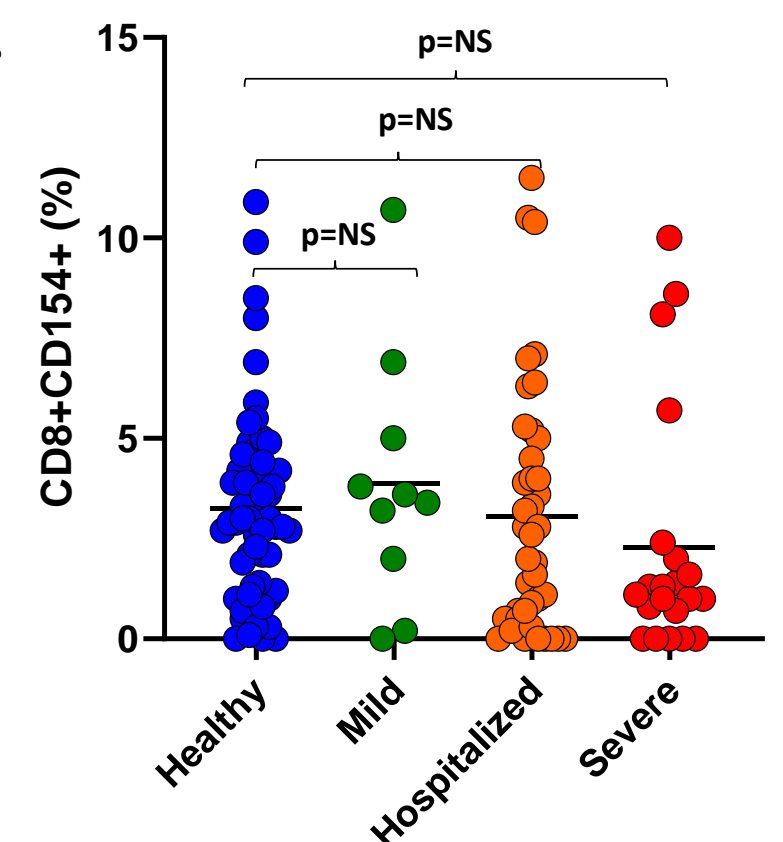


a.

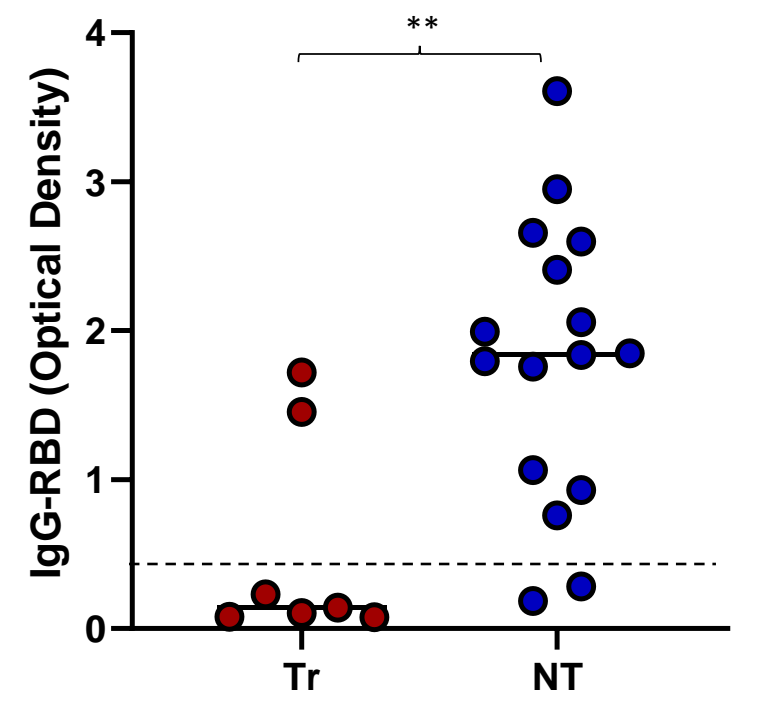

b.

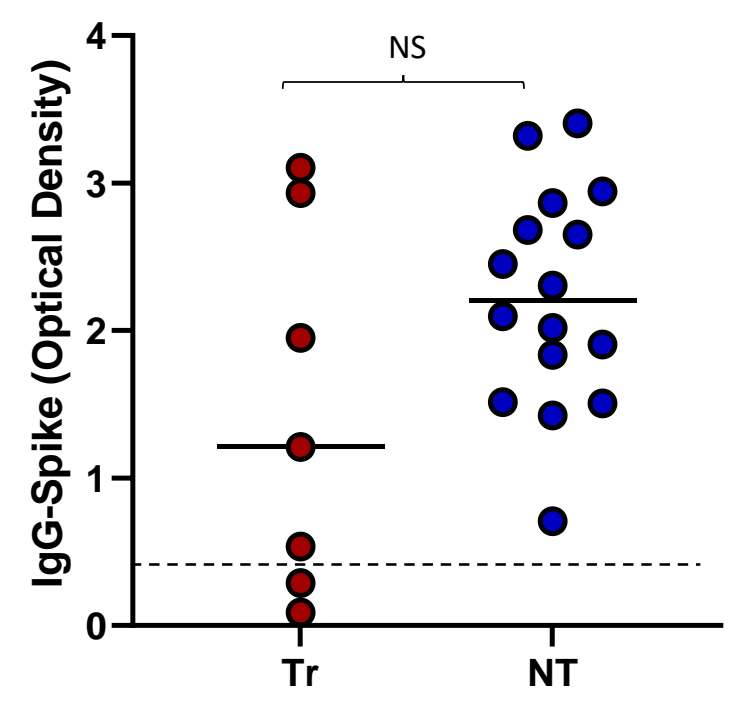

c.

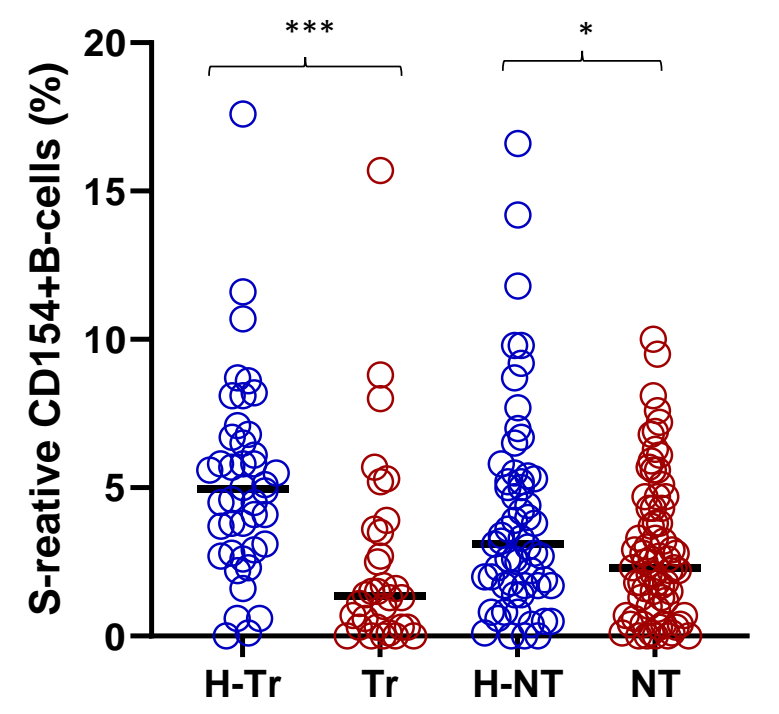


a.

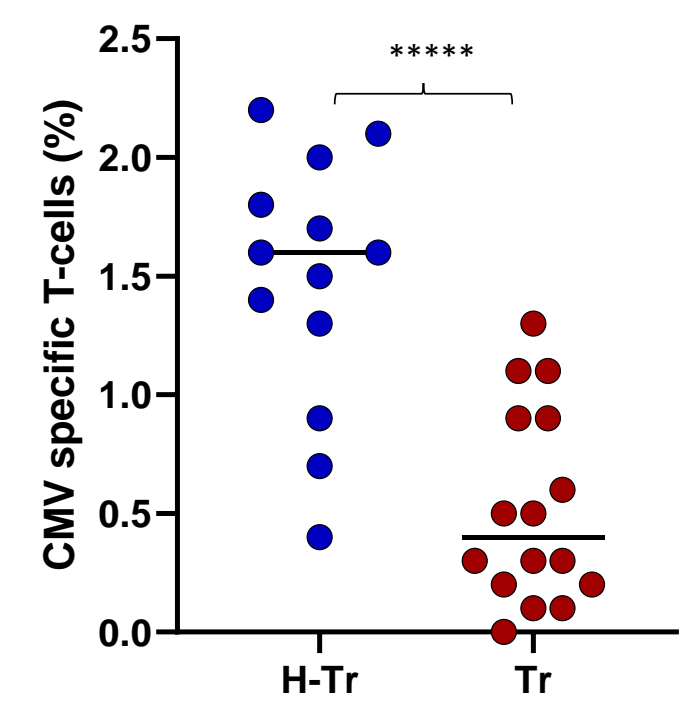

c.

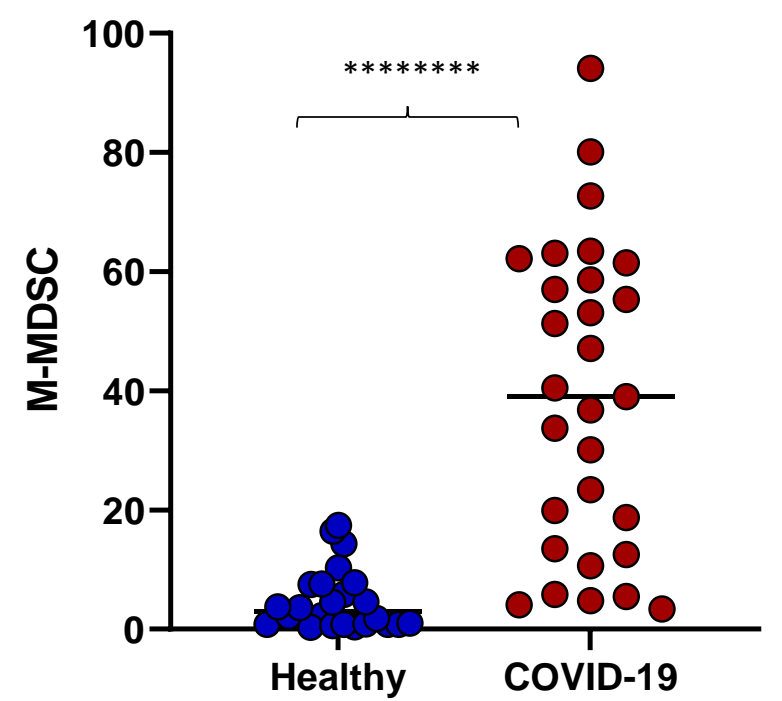

b.

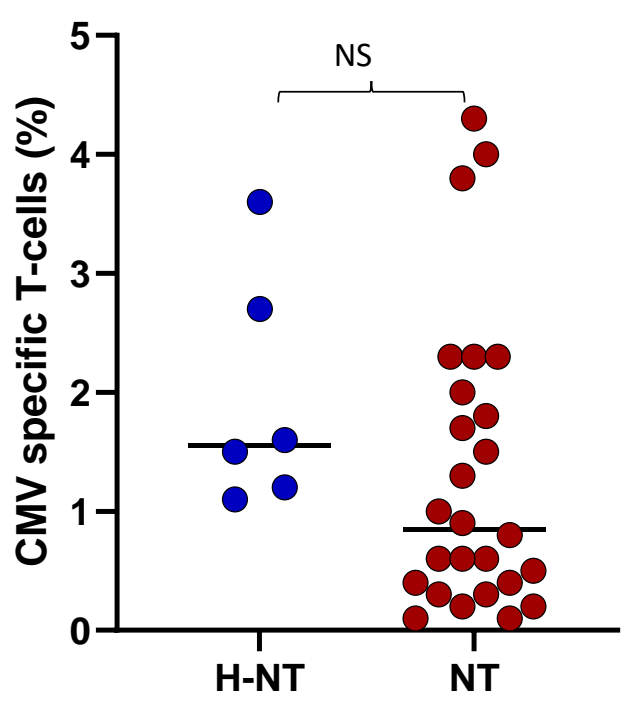

d.

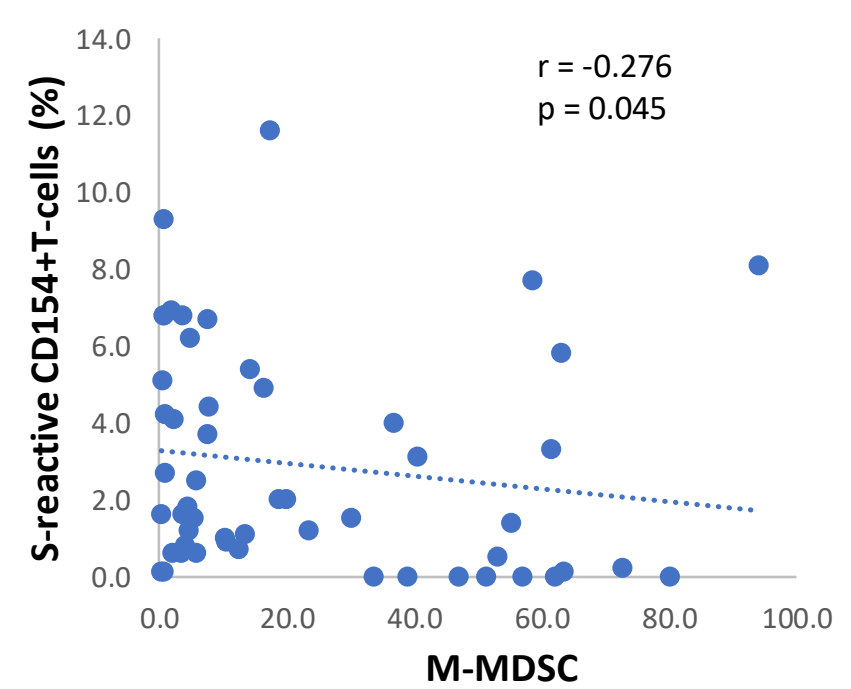


Figure S1.
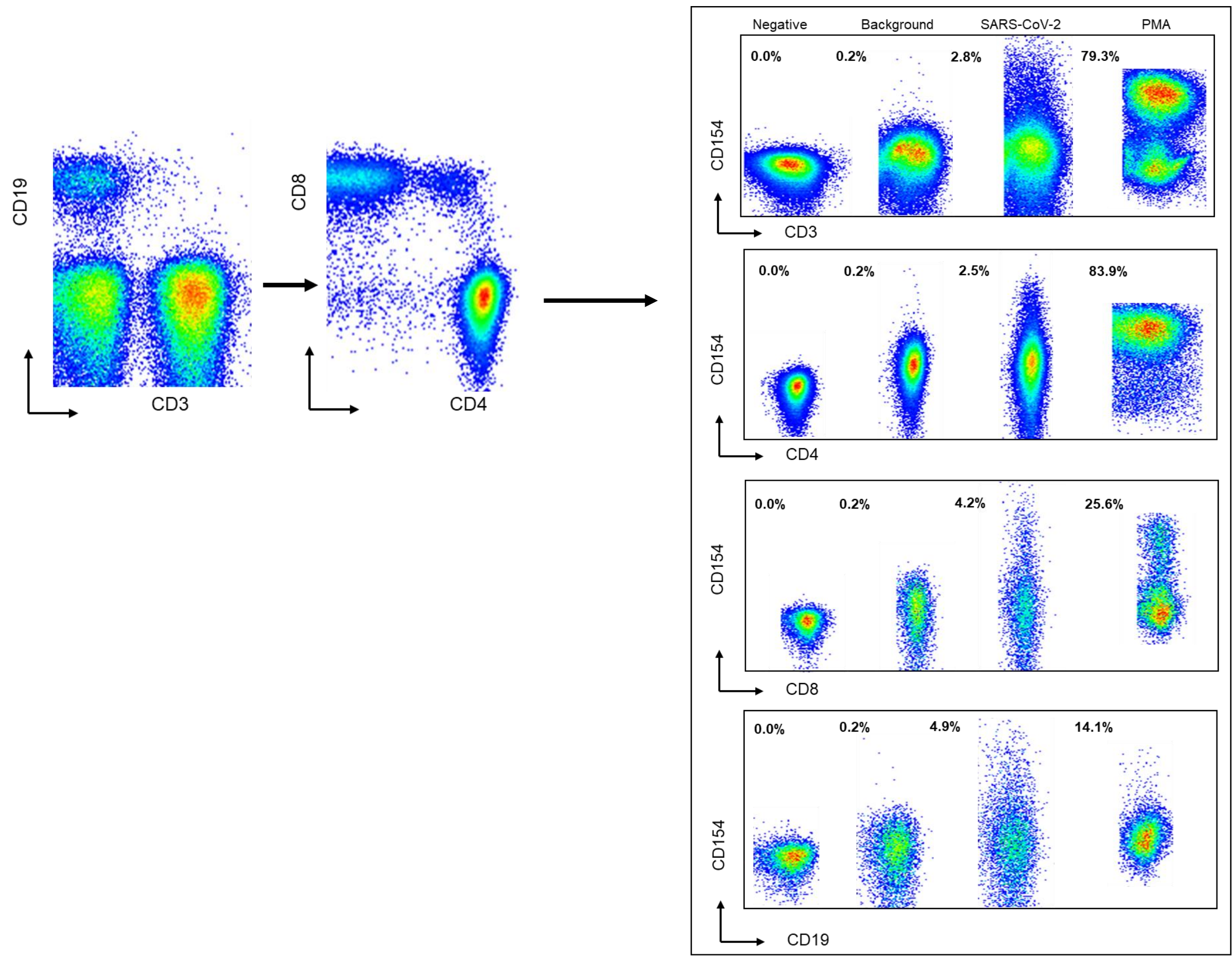
Table S1: Demographics, treatment and outcomes of 66 patients with COVID-19 infection. Type (Tr= Transplant, NT= No-Transplant), Race $(C=$ Caucasian, $A A=A$ frican American, $H=$ Hispanic, $A=A$ sian), Status $(A=A$ live, $D=D e a d)$, Plasma treatment $(N=N o, Y=Y e s)$, Dexamethasone / Prednisone. Dexamethasone is given as part of the COVID-19 treatment regime, Prednisone is given to transplant patients as part of maintenance immunosuppression.

\begin{tabular}{|c|c|c|c|c|c|c|c|c|}
\hline Type & Race & Age & Gender & $\begin{array}{c}\text { Days from } \\
\text { diagnosis }\end{array}$ & $\begin{array}{l}\text { Disease } \\
\text { Severity }\end{array}$ & Status & $\begin{array}{c}\text { Plasma } \\
\text { treatment }\end{array}$ & $\begin{array}{c}\text { Dexamethasone / } \\
\text { Prednisone }\end{array}$ \\
\hline NT & $\mathrm{C}$ & 47 & $\mathrm{~F}$ & 18 & Intubated & A & $Y$ & Dexamethasone \\
\hline NT & $\mathrm{H}$ & 61 & $M$ & 14 & Intubated & A & $Y$ & Dexamethasone \\
\hline NT & $\mathrm{H}$ & 63 & $\mathrm{~F}$ & 26 & Intubated & $A$ & $Y$ & Dexamethasone \\
\hline NT & $\mathrm{H}$ & 44 & $\mathrm{~F}$ & 21 & Intubated & A & $Y$ & Dexamethasone \\
\hline NT & $\mathrm{H}$ & 59 & $M$ & 0 & Intubated & $A$ & $Y$ & Dexamethasone \\
\hline NT & $\mathrm{H}$ & 48 & $\mathrm{~F}$ & 22 & Intubated & $\mathrm{D}$ & $Y$ & Dexamethasone \\
\hline NT & $\mathrm{H}$ & 69 & $M$ & 6 & Intubated & $\mathrm{D}$ & $Y$ & Dexamethasone \\
\hline NT & $\mathrm{H}$ & 74 & $M$ & 88 & Intubated & A & $Y$ & Dexamethasone \\
\hline NT & $\mathrm{H}$ & 71 & $M$ & 4 & Intubated & $A$ & $Y$ & Dexamethasone \\
\hline NT & $\mathrm{H}$ & 61 & $M$ & 18 & Intubated & $A$ & $Y$ & Dexamethasone \\
\hline NT & $\mathrm{H}$ & 67 & $M$ & 17 & Intubated & $A$ & $Y$ & None \\
\hline NT & $\mathrm{H}$ & 57 & $M$ & 14 & Intubated & $A$ & $Y$ & $\mathrm{~N}$ \\
\hline NT & $\mathrm{H}$ & 45 & $M$ & 15 & Intubated & $A$ & $Y$ & $\mathrm{~N}$ \\
\hline NT & $\mathrm{H}$ & 53 & $M$ & 29 & Intubated & $A$ & $Y$ & $\mathrm{~N}$ \\
\hline NT & $\mathrm{H}$ & 58 & $\mathrm{~F}$ & 26 & Intubated & $A$ & $Y$ & $\mathrm{~N}$ \\
\hline NT & $\mathrm{H}$ & 70 & $\mathrm{~F}$ & 16 & Intubated & A & $Y$ & $\mathrm{~N}$ \\
\hline NT & $\mathrm{H}$ & 70 & $M$ & 19 & Intubated & $\mathrm{D}$ & $Y$ & $\mathrm{~N}$ \\
\hline NT & AA & 24 & $\mathrm{~F}$ & 2 & Intubated & $\mathrm{D}$ & $\mathrm{N}$ & $\mathrm{N}$ \\
\hline NT & $\mathrm{H}$ & 57 & $\mathrm{~F}$ & 14 & Intubated & $A$ & $Y$ & $\mathrm{~N}$ \\
\hline
\end{tabular}




\begin{tabular}{|c|c|c|c|c|c|c|c|c|}
\hline NT & $\mathrm{H}$ & 77 & $\mathrm{~F}$ & 4 & Intubated & A & $Y$ & $\mathrm{~N}$ \\
\hline NT & $\mathrm{H}$ & 54 & $\mathrm{~F}$ & 5 & Intubated & $A$ & $\mathrm{Y}$ & $\mathrm{N}$ \\
\hline NT & $\mathrm{H}$ & 30 & $M$ & 1 & Hospitalized & $A$ & $\mathrm{~N}$ & Dexamethasone \\
\hline NT & $\mathrm{H}$ & 47 & $M$ & 30 & Hospitalized & $A$ & $\mathrm{~N}$ & Dexamethasone \\
\hline NT & $\mathrm{H}$ & 32 & $M$ & 3 & Hospitalized & A & $\mathrm{Y}$ & Dexamethasone \\
\hline NT & $\mathrm{H}$ & 34 & $\mathrm{~F}$ & 11 & Hospitalized & $A$ & $Y$ & Dexamethasone \\
\hline NT & $\mathrm{H}$ & 44 & $\mathrm{~F}$ & 2 & Hospitalized & $A$ & $Y$ & Dexamethasone \\
\hline NT & $\mathrm{H}$ & 56 & $M$ & 5 & Hospitalized & $A$ & $Y$ & Dexamethasone \\
\hline NT & $\mathrm{H}$ & 24 & $M$ & 7 & Hospitalized & $A$ & $\mathrm{Y}$ & Dexamethasone \\
\hline NT & $\mathrm{H}$ & 55 & $M$ & 4 & Hospitalized & $A$ & $\mathrm{Y}$ & Dexamethasone \\
\hline NT & $\mathrm{H}$ & 35 & $\mathrm{~F}$ & 11 & Hospitalized & $\mathrm{A}$ & $Y$ & Dexamethasone \\
\hline NT & $\mathrm{H}$ & 51 & $M$ & 8 & Hospitalized & A & $Y$ & Dexamethasone \\
\hline NT & $\mathrm{H}$ & 68 & $M$ & 3 & Hospitalized & $A$ & $Y$ & Dexamethasone \\
\hline NT & $\mathrm{H}$ & 65 & $\mathrm{~F}$ & 5 & Hospitalized & $A$ & $Y$ & Dexamethasone \\
\hline NT & $\mathrm{H}$ & 87 & $\mathrm{~F}$ & 6 & Hospitalized & $A$ & $\mathrm{Y}$ & Dexamethasone \\
\hline NT & $\mathrm{H}$ & 35 & $\mathrm{~F}$ & 0 & Hospitalized & $A$ & $\mathrm{Y}$ & Dexamethasone \\
\hline NT & $\mathrm{H}$ & 70 & $M$ & 1 & Hospitalized & $\mathrm{A}$ & $Y$ & Dexamethasone \\
\hline NT & $\mathrm{H}$ & 79 & $M$ & 0 & Hospitalized & $\mathrm{A}$ & $Y$ & Dexamethasone \\
\hline NT & $\mathrm{H}$ & 83 & $M$ & 0 & Hospitalized & A & $Y$ & Dexamethasone \\
\hline NT & $\mathrm{H}$ & 72 & $M$ & 0 & Hospitalized & $A$ & $Y$ & Dexamethasone \\
\hline NT & $\mathrm{H}$ & 75 & $\mathrm{~F}$ & 0 & Hospitalized & $A$ & $Y$ & Dexamethasone \\
\hline NT & $\mathrm{H}$ & 69 & $M$ & 0 & Hospitalized & $\mathrm{A}$ & $Y$ & Dexamethasone \\
\hline NT & $\mathrm{H}$ & 50 & $M$ & 0 & Hospitalized & $A$ & $Y$ & Dexamethasone \\
\hline NT & $\mathrm{C}$ & 51 & $\mathrm{~F}$ & 94 & Hospitalized & $A$ & $Y$ & Dexamethasone \\
\hline NT & $\mathrm{H}$ & 74 & $\mathrm{M}$ & 3 & Hospitalized & A & $Y$ & Dexamethasone \\
\hline NT & $\mathrm{H}$ & 65 & $M$ & 27 & Hospitalized & A & $Y$ & Dexamethasone \\
\hline NT & $\mathrm{H}$ & 87 & $\mathrm{~F}$ & 8 & Hospitalized & $\mathrm{A}$ & $Y$ & Dexamethasone \\
\hline NT & $\mathrm{C}$ & 72 & $\mathrm{~F}$ & 4 & Hospitalized & $A$ & $Y$ & Dexamethasone \\
\hline NT & $\mathrm{H}$ & 65 & $\mathrm{~F}$ & 1 & Hospitalized & A & $Y$ & Dexamethasone \\
\hline NT & $\mathrm{H}$ & 73 & $M$ & 2 & Hospitalized & A & $Y$ & Dexamethasone \\
\hline
\end{tabular}




\begin{tabular}{|c|c|c|c|c|c|c|c|c|}
\hline NT & $\mathrm{H}$ & 49 & $\mathrm{~F}$ & 2 & Hospitalized & A & $\mathrm{N}$ & None \\
\hline NT & $\mathrm{H}$ & 78 & $\mathrm{M}$ & 8 & Hospitalized & $A$ & $\mathrm{~N}$ & None \\
\hline NT & $\mathrm{H}$ & 65 & $M$ & 1 & Hospitalized & $A$ & $Y$ & None \\
\hline NT & $\mathrm{H}$ & 33 & $M$ & 28 & Hospitalized & $A$ & $Y$ & None \\
\hline NT & $\mathrm{H}$ & 52 & $M$ & 27 & Hospitalized & $A$ & $Y$ & None \\
\hline NT & $A A$ & 63 & $\mathrm{~F}$ & 2 & Hospitalized & $A$ & $\mathrm{~N}$ & None \\
\hline NT & $A A$ & 69 & $M$ & 2 & Hospitalized & $A$ & $\mathrm{~N}$ & None \\
\hline NT & $\mathrm{H}$ & 78 & $\mathrm{~F}$ & 3 & Hospitalized & $A$ & $\mathrm{~N}$ & None \\
\hline NT & $\mathrm{H}$ & 66 & $\mathrm{~F}$ & 1 & Hospitalized & $A$ & $\mathrm{~N}$ & None \\
\hline NT & $\mathrm{H}$ & 69 & $M$ & 0 & Hospitalized & $A$ & $\mathrm{~N}$ & None \\
\hline NT & $\mathrm{H}$ & 53 & $\mathrm{~F}$ & 9 & Hospitalized & $A$ & $\mathrm{Y}$ & None \\
\hline NT & $A A$ & 65 & $M$ & 2 & Hospitalized & $A$ & $\mathrm{~N}$ & Dexamethasone \\
\hline NT & $C$ & 46 & $M$ & 18 & Mild/Asymp & $A$ & $\mathrm{~N}$ & None \\
\hline NT & $A$ & 32 & $M$ & 16 & Mild/Asymp & $A$ & $\mathrm{~N}$ & None \\
\hline NT & $C$ & 36 & $M$ & 14 & Mild/Asymp & $A$ & $\mathrm{~N}$ & None \\
\hline NT & $C$ & 26 & $\mathrm{~F}$ & 14 & Mild/Asymp & $A$ & $\mathrm{~N}$ & None \\
\hline NT & $\mathrm{C}$ & 39 & $M$ & 16 & Mild/Asymp & $A$ & $\mathrm{~N}$ & None \\
\hline NT & $C$ & 25 & $\mathrm{~F}$ & 18 & Mild/Asymp & $A$ & $\mathrm{~N}$ & None \\
\hline NT & $C$ & 28 & $\mathrm{~F}$ & 16 & Mild/Asymp & $A$ & $\mathrm{~N}$ & None \\
\hline NT & $C$ & 25 & $\mathrm{~F}$ & 24 & Mild/Asymp & $A$ & $\mathrm{~N}$ & None \\
\hline NT & $C$ & 51 & $\mathrm{~F}$ & 26 & Mild/Asymp & $A$ & $\mathrm{~N}$ & None \\
\hline NT & $\mathrm{C}$ & 38 & $\mathrm{~F}$ & 21 & Mild/Asymp & $\mathrm{A}$ & $\mathrm{N}$ & None \\
\hline $\mathrm{Tr}$ & $A A$ & 53 & $M$ & 2 & Intubated & $A$ & $\mathrm{~N}$ & Prednisone \\
\hline $\operatorname{Tr}$ & $\mathrm{H}$ & 76 & $M$ & 14 & Intubated & $A$ & $y$ & Prednisone \\
\hline $\mathrm{Tr}$ & $\mathrm{H}$ & 58 & $M$ & 29 & Intubated & $A$ & $\mathrm{~N}$ & Prednisone \\
\hline $\operatorname{Tr}$ & $\mathrm{H}$ & 45 & $M$ & 4 & Intubated & $A$ & $\mathrm{~N}$ & Prednisone \\
\hline $\mathrm{Tr}$ & AA & 43 & $\mathrm{~F}$ & 4 & Intubated & A & $\mathrm{N}$ & Prednisone \\
\hline $\mathrm{Tr}$ & $C$ & 75 & $\mathrm{~F}$ & 4 & Intubated & $A$ & $\mathrm{~N}$ & Prednisone \\
\hline $\mathrm{Tr}$ & $C$ & 63 & $M$ & 26 & Intubated & $A$ & $\mathrm{~N}$ & Prednisone \\
\hline $\mathrm{Tr}$ & $C$ & 68 & $M$ & 7 & Intubated & $D$ & $\mathrm{~N}$ & Prednisone \\
\hline
\end{tabular}




\begin{tabular}{|c|c|c|c|c|c|c|c|c|}
\hline $\operatorname{Tr}$ & $\mathrm{AA}$ & 44 & $\mathrm{~F}$ & 19 & Intubated & $\mathrm{D}$ & $\mathrm{N}$ & Prednisone \\
\hline $\mathrm{Tr}$ & $\mathrm{C}$ & 73 & $M$ & 23 & Intubated & $\mathrm{D}$ & $\mathrm{N}$ & Prednisone \\
\hline $\operatorname{Tr}$ & $\mathrm{C}$ & 46 & $M$ & 43 & Intubated & $\mathrm{D}$ & $\mathrm{N}$ & Prednisone \\
\hline $\mathrm{Tr}$ & $\mathrm{H}$ & 62 & $M$ & 17 & Intubated & $\mathrm{D}$ & $Y$ & Prednisone \\
\hline $\mathrm{Tr}$ & AA & 72 & $M$ & 26 & Hospitalized & $A$ & $\mathrm{~N}$ & Prednisone \\
\hline $\mathrm{Tr}$ & $\mathrm{H}$ & 75 & $M$ & 5 & Hospitalized & $A$ & $\mathrm{~N}$ & Prednisone \\
\hline $\mathrm{Tr}$ & AA & 77 & $\mathrm{~F}$ & 11 & Hospitalized & $A$ & $\mathrm{~N}$ & Prednisone \\
\hline $\mathrm{Tr}$ & $C$ & 41 & $M$ & 2 & Hospitalized & $A$ & $\mathrm{~N}$ & Prednisone \\
\hline $\mathrm{Tr}$ & $\mathrm{H}$ & 15 & $M$ & 3 & Hospitalized & $A$ & $\mathrm{~N}$ & Prednisone \\
\hline $\mathrm{Tr}$ & $\mathrm{H}$ & 67 & $\mathrm{~F}$ & 14 & Hospitalized & $\mathrm{A}$ & $\mathrm{N}$ & Prednisone \\
\hline $\mathrm{Tr}$ & $\mathrm{C}$ & 75 & $\mathrm{~F}$ & 9 & Hospitalized & $\mathrm{A}$ & $\mathrm{N}$ & Prednisone \\
\hline $\mathrm{Tr}$ & AA & 33 & $\mathrm{~F}$ & 5 & Hospitalized & $A$ & $\mathrm{~N}$ & Prednisone \\
\hline $\mathrm{Tr}$ & AA & 44 & $M$ & 5 & Hospitalized & $A$ & $\mathrm{~N}$ & Prednisone \\
\hline $\mathrm{Tr}$ & $\mathrm{AA}$ & 64 & $\mathrm{~F}$ & 2 & Hospitalized & $A$ & $\mathrm{~N}$ & Prednisone \\
\hline $\operatorname{Tr}$ & $C$ & 51 & $\mathrm{~F}$ & 2 & Hospitalized & $A$ & $\mathrm{~N}$ & Prednisone \\
\hline $\mathrm{Tr}$ & $\mathrm{AA}$ & 43 & $M$ & 2 & Hospitalized & $A$ & $\mathrm{~N}$ & Prednisone \\
\hline $\mathrm{Tr}$ & $\mathrm{H}$ & 39 & $M$ & 11 & Hospitalized & $\mathrm{A}$ & $\mathrm{N}$ & Prednisone \\
\hline $\operatorname{Tr}$ & $\mathrm{AA}$ & 68 & $\mathrm{M}$ & 32 & Hospitalized & $\mathrm{A}$ & $\mathrm{N}$ & Prednisone \\
\hline $\operatorname{Tr}$ & $\mathrm{AA}$ & 31 & $M$ & 6 & Hospitalized & A & $\mathrm{N}$ & Prednisone \\
\hline $\operatorname{Tr}$ & A & 1 & $M$ & 3 & Hospitalized & $A$ & $\mathrm{~N}$ & None \\
\hline $\operatorname{Tr}$ & $\mathrm{H}$ & 51 & $\mathrm{~F}$ & 5 & Hospitalized & A & $\mathrm{Y}$ & Prednisone \\
\hline $\operatorname{Tr}$ & $\mathrm{H}$ & 7 & $\mathrm{~F}$ & 3 & Hospitalized & $\mathrm{A}$ & $\mathrm{Y}$ & None \\
\hline $\mathrm{Tr}$ & $\mathrm{H}$ & 1 & $M$ & 50 & Mild/Asymp & $A$ & $\mathrm{~N}$ & Prednisone \\
\hline $\mathrm{Tr}$ & $A$ & 17 & $M$ & 30 & Mild/Asymp & $\mathrm{A}$ & $\mathrm{N}$ & Prednisone \\
\hline
\end{tabular}




\section{SUPPLEMENTARY TABLES}

Table S2: Summary of variation in CD154+PBL subsets (CD3, CD4, CD8, CD19) measured in same-day duplicate testing of five PBL samples in response to spike protein (upper half of table) and PMA stimulation (lower half of table). Variation is measured as the coefficient of variation (CV $\%)$.

\begin{tabular}{|}
\begin{tabular}{|c|c|c|c|c|c|c|c|c|}
\hline Spike & N & Mean CV & Cl low & Cl-up & SD & Median & Min & Max \\
\hline CD3 & 5.0 & 3.0 & -0.8 & 6.8 & 4.3 & 1.9 & 0.0 & 10.4 \\
\hline CD4 & 5.0 & 5.0 & -0.5 & 10.5 & 6.3 & 2.2 & 0.0 & 14.6 \\
\hline CD8 & 5.0 & 3.3 & -0.2 & 6.8 & 3.9 & 1.8 & 0.0 & 10.0 \\
\hline CD19 & 5.0 & 2.0 & 0.9 & 3.2 & 1.3 & 2.0 & 0.0 & 3.6 \\
\hline PMA & N & Mean CV & Cl low & Cl-up & SD & Median & Min & Max \\
\hline CD3 & 5.0 & 3.6 & 2.1 & 5.1 & 1.7 & 4.4 & 1.1 & 5.0 \\
\hline CD4 & 5.0 & 2.6 & -0.5 & 5.8 & 3.6 & 2.0 & 0.1 & 8.8 \\
\hline CD8 & 5.0 & 3.5 & 1.9 & 5.1 & 1.8 & 3.7 & 1.3 & 6.2 \\
\hline CD19 & 5.0 & 3.0 & 0.8 & 5.2 & 2.5 & 2.0 & 0.8 & 6.7 \\
\hline
\end{tabular}
\end{tabular}


Table S3: Summary of variation in CD154+PBL subsets (CD3, CD4, CD8, CD19) measured in five PBL samples tested on the day of phlebotomy and after cryopreservation for 7 days. All samples were stimulated with spike protein (upper half of table) and PMA (lower half of table). Variation is measured as the coefficient of variation (CV \%).

\begin{tabular}{|}
\begin{tabular}{|c|c|c|c|c|c|c|c|c|}
\hline Spike & N & Mean CV & Cl low & Cl-up & SD & Median & Min & Max \\
\hline CD3 & 5.0 & 3.8 & -2.0 & 9.7 & 6.7 & 1.6 & 0.0 & 15.7 \\
\hline CD4 & 5.0 & 10.6 & -7.4 & 28.5 & 20.5 & 2.1 & 0.0 & 47.1 \\
\hline CD8 & 5.0 & 3.0 & -0.1 & 6.0 & 3.4 & 1.6 & 0.0 & 8.7 \\
\hline CD19 & 5.0 & 7.5 & 1.2 & 13.8 & 7.2 & 9.1 & 0.0 & 15.7 \\
\hline PMA & N & Mean CV & Cl low & Cl-up & SD & Median & Min & Max \\
\hline CD3 & 5.0 & 5.3 & 2.4 & 8.2 & 3.3 & 6.3 & 0.4 & 8.3 \\
\hline CD4 & 5.0 & 4.3 & 1.0 & 7.7 & 3.8 & 2.7 & 1.9 & 11.1 \\
\hline CD8 & 5.0 & 4.9 & 0.6 & 9.2 & 4.9 & 3.2 & 1.7 & 13.6 \\
\hline CD19 & 5.0 & 2.4 & 0.7 & 4.0 & 1.9 & 2.0 & 0.0 & 4.8 \\
\hline
\end{tabular}
\end{tabular}


Table S4. Summary of variation in CD154+PBL subsets (CD3, CD4, CD8, CD19) measured in five PBL samples tested on the day of phlebotomy and after overnight storage at room temperature. All samples were stimulated with spike protein (upper half of table) and PMA (lower half of table). Variation is measured as the coefficient of variation (CV \%).

\begin{tabular}{|c|c|c|c|c|c|c|c|c|}
\hline Spike & $\mathbf{N}$ & Mean CV & Cl low & Cl-up & SD & Median & Min & Max \\
\hline CD3 & 5.0 & 6.3 & 0.1 & 12.6 & 7.1 & 4.0 & 0.0 & 15.7 \\
\hline CD4 & 5.0 & 7.8 & 1.3 & 14.3 & 7.4 & 2.8 & 2.1 & 16.1 \\
\hline CD8 & 5.0 & 6.6 & 0.6 & 12.5 & 6.8 & 1.9 & 1.2 & 15.1 \\
\hline CD19 & 5.0 & 6.5 & 2.8 & 10.2 & 4.2 & 4.7 & 2.8 & 13.1 \\
\hline
\end{tabular}

\begin{tabular}{|c|c|c|c|c|c|c|c|c|}
\hline PMA & N & Mean CV & Cl low & Cl-up & SD & Median & Min & Max \\
\hline CD3 & 5.0 & 3.9 & 0.4 & 7.4 & 4.0 & 2.5 & 0.4 & 10.7 \\
\hline CD4 & 5.0 & 3.4 & 0.9 & 5.9 & 2.9 & 3.4 & 0.7 & 7.8 \\
\hline CD8 & 5.0 & 6.2 & 1.4 & 11.1 & 5.5 & 5.6 & 1.1 & 15.5 \\
\hline CD19 & 5.0 & 5.4 & 3.2 & 7.6 & 2.5 & 6.0 & 2.0 & 7.8 \\
\hline
\end{tabular}


Table S5. Summary of variation in CD154+PBL subsets (CD3, CD4, CD8, CD19) measured in five PBL samples tested on the day of phlebotomy and after overnight shipment at ambient temperature. All samples were stimulated with spike protein (upper half of table) and PMA (lower half of table). Variation is measured as the coefficient of variation (CV \%).

\begin{tabular}{|c|c|c|c|c|c|c|c|c|}
\hline Spike & $\mathbf{N}$ & Mean CV & Cl low & Cl-up & SD & Median & Min & Max \\
\hline CD3 & 5.0 & 7.2 & 1.9 & 12.5 & 6.0 & 6.0 & 0.0 & 15.7 \\
\hline CD4 & 5.0 & 9.3 & 2.2 & 16.4 & 8.1 & 4.4 & 2.1 & 20.2 \\
\hline CD8 & 5.0 & 4.0 & 0.2 & 7.8 & 4.3 & 3.3 & 0.0 & 11.3 \\
\hline CD19 & 5.0 & 4.6 & 1.3 & 8.0 & 3.8 & 2.8 & 1.0 & 9.1 \\
\hline
\end{tabular}

\begin{tabular}{|c|c|c|c|c|c|c|c|c|}
\hline PMA & N & Mean CV & Cl low & Cl-up & SD & Median & Min & Max \\
\hline CD3 & 5.0 & 4.1 & 0.8 & 7.5 & 3.8 & 1.9 & 1.4 & 10.4 \\
\hline CD4 & 5.0 & 3.0 & 1.4 & 4.6 & 1.8 & 2.8 & 1.1 & 5.2 \\
\hline CD8 & 5.0 & 5.7 & 3.9 & 7.5 & 2.0 & 5.3 & 3.2 & 8.8 \\
\hline CD19 & 5.0 & 3.2 & 0.1 & 6.3 & 3.5 & 1.5 & 0.0 & 7.2 \\
\hline
\end{tabular}


Table S6. Summary data for mean and median frequencies of S-reactive CD154+PBL subsets.

\begin{tabular}{|c|c|c|c|c|c|}
\hline & & CD3 & CD4 & CD8 & CD19 \\
\hline \multirow{3}{*}{$\begin{array}{l}\text { Healthy-NT } \\
\quad(\mathrm{N}=59)\end{array}$} & Mean & 3.1 & 2.8 & 3.2 & 4.0 \\
\hline & Median & 2.6 & 2.3 & 3.0 & 3.1 \\
\hline & SD & 3.0 & 2.5 & 2.3 & 3.5 \\
\hline \multirow{3}{*}{$\begin{array}{l}\text { Healthy-Tr } \\
(\mathrm{N}=42)\end{array}$} & Mean & 4.2 & 4.0 & 5.0 & 5.2 \\
\hline & Median & 4.2 & 3.8 & 4.8 & 5.0 \\
\hline & SD & 2.4 & 2.2 & 3.2 & 3.3 \\
\hline \multirow{3}{*}{$\begin{array}{l}\text { COVID-19-NT } \\
(\mathrm{N}=71)\end{array}$} & Mean & 2.2 & 1.9 & 2.9 & 2.9 \\
\hline & Median & 1.5 & 1.3 & 1.9 & 2.3 \\
\hline & SD & 2.1 & 1.8 & 3.1 & 2.4 \\
\hline \multirow{3}{*}{$\begin{array}{l}\text { COVID-19-Tr } \\
\quad(\mathrm{N}=32)\end{array}$} & Mean & 1.8 & 1.8 & 2.2 & 2.5 \\
\hline & Median & 0.7 & 0.6 & 0.5 & 1.4 \\
\hline & SD & 2.6 & 2.5 & 3.1 & 3.4 \\
\hline \multirow{3}{*}{ p-value } & H-NT vs H-Tr & 0.0422 & 0.0147 & 0.0043 & 0.0755 \\
\hline & H-NT vs NT & 0.0437 & 0.0222 & 0.5310 & 0.0497 \\
\hline & $\mathrm{H}-\mathrm{Tr}$ vs $\mathrm{Tr}$ & 0.0001 & 0.0002 & 0.0004 & 0.0010 \\
\hline
\end{tabular}

